\section{Supraglottic Devices in Lapa- roscopic Surgery - A Review of Literature}

\section{Shalini Subramanian* and Divya Sethi \\ ESI PGIMSR and Associated Hospital, Basaidarapur, New Delhi, India}

\begin{abstract}
Supraglottic Airway Devices (SAD) offer several advantages over endotracheal intubation including reduced hemodynamic response, decreased anaesthetic requirement for airway tolerance and lesser pharyngolaryngeal morbidity. Second generation SADs incorporate a drain tube in their construction to separate the respiratory and alimentary tract. They offer better oropharyngeal seal and improved protection against regurgitation and aspiration. Laparoscopic Surgery (LS) involves generation of pneumoperitoneum and positioning with head up or head down tilt with resultant cardiovascular and respiratory effects. LS offer the ultimate test for the efficacy of SAD use in the face of changes in intra-abdominal pressure and thoracic compliance. Careful choice of the anesthetic technique and patient selection has allowed effective use of SAD in LS. This review seeks to explore the use of second generation SAD with particular reference to PLMA, SLMA and i-gel in laparoscopic surgery.
\end{abstract}

\section{Introduction}

Supraglottic Airway Devices (SADs) made their entry into the anesthesiologist's armamentarium in 1983 with the introduction of the Classic Laryngeal Mask Airway (CLMA) [1]. Their use in Laparoscopic Surgery (LS) has been described a non conventional use but feasible [2]. The second generation SADs with an esophageal vent has been developed to improve airway seal and decrease the risk of aspiration [3]. Lu et al., have shown the better suitability of SAD with a drain tube for securing the airway in laparoscopic procedures [4]. This review seeks to detail the literature on use of second generation SADs in laparoscopic surgery with reference to Proseal Laryngeal Mask Airway (PLMA), LMA- Supreme (SLMA) and Inter-surgical i-gel (i-gel).

We searched the database of MEDLINE, Scopus, Cochrane for English language studies between 1997 and 2014 using the keywords laryngeal mask airway, LMA, ProSeal LMA, PLMA, Supreme LMA, SLMA, i-gel, laparoscopic. The year 1997 was chosen as the starting point as ProSeal LMA came into clinical use soon after in 2000.

*Corresponding author: Shalini Subramanian, ESI PGIMSR and Associated Hospital, Basaidarapur, New Delhi - 110015, India, Tel: +91 7406610222; E-mail: drshalinisubramanian@gmail.com

Citation: Subramanian S, Divya S (2016) Supraglottic Devices in Laparoscopic Surgery - A Review of Literature. J Anesth Clin Care 3: 013.

Received: August 7, 2015; Accepted: January 20, 2016; Published: February 01, 2016
Device Description

\begin{tabular}{|c|c|c|c|}
\hline & PLMA (Figure 1a) & SLMA (Figure 1b) & I-gel (Figure 1c) \\
\hline $\begin{array}{l}\text { Year of intro- } \\
\text { duction }\end{array}$ & 2000 & 2007 & 2007 \\
\hline Material & $\begin{array}{l}\text { Medical grade } \\
\text { silicone, reusable } \\
\text { (autoclavable) }\end{array}$ & $\mathrm{PVC}$, single use & $\begin{array}{l}\text { Gel like thermo- } \\
\text { plastic elastomer } \\
\text { (Styrene ethylene } \\
\text { butadiene sty- } \\
\text { rene), single use }\end{array}$ \\
\hline $\begin{array}{l}\text { Sizes avail- } \\
\text { able }\end{array}$ & $1,1.5,2,2.5,3,4,5$ & $1,1.5,2,2.5,3,4,5$ & $1,1.5,2,2.5,3,4,5$ \\
\hline Description & $\begin{array}{l}\text { Reinforced airway } \\
\text { tube, bowl and } \\
\text { inflatable double } \\
\text { cuff (single in } \\
\text { size<3), silicone } \\
\text { drain tube, bite } \\
\text { block and pocket } \\
\text { for introducer }\end{array}$ & $\begin{array}{l}\text { Preformed curved } \\
\text { shaft consists of } \\
\text { a double lumen, } \\
\text { i.e., a central drain } \\
\text { tube encased } \\
\text { within a flattened } \\
\text { oval-shaped airway } \\
\text { lumen, inflatable } \\
\text { single cuff, a built-in } \\
\text { bite block and } \\
\text { moulded fins at the } \\
\text { laryngeal outlet to } \\
\text { prevent epiglottic } \\
\text { obstruction }\end{array}$ & $\begin{array}{l}\text { Cuffless device } \\
\text { anatomically de- } \\
\text { signed to conform } \\
\text { to the shape of } \\
\text { hypo-pharynx with } \\
\text { drain tube and } \\
\text { integrated bite } \\
\text { block }\end{array}$ \\
\hline $\begin{array}{l}\text { Drain tube } \\
\text { characteris- } \\
\text { tics }\end{array}$ & $\begin{array}{l}\text { Runs through } \\
\text { device from tip } \\
\text { to proximal end } \\
\text { by the side of the } \\
\text { airway tube }\end{array}$ & $\begin{array}{l}\text { Runs through } \\
\text { the middle of the } \\
\text { semi-rigid airway } \\
\text { tube dividing it into } \\
\text { two halves }\end{array}$ & $\begin{array}{l}\text { Narrower bore } \\
\text { drain tube with } \\
\text { truncated tip that } \\
\text { penetrates lesser } \\
\text { into the esoph- } \\
\text { ageal inlet in } \\
\text { comparison with } \\
\text { PLMA or SLMA }\end{array}$ \\
\hline $\begin{array}{l}\text { Size of gastric } \\
\text { tube }\end{array}$ & $\begin{array}{l}\text { PLMA } 3: 16 \mathrm{Fr} \\
\text { PLMA } 4: 16 \mathrm{Fr} \\
\text { PLMA } 5: 18 \mathrm{Fr}\end{array}$ & $\begin{array}{l}\text { SLMA } 3: 14 \mathrm{Fr} \\
\text { SLMA } 4: 14 \mathrm{Fr} \\
\text { SLMA } 5: 14 \mathrm{Fr}\end{array}$ & $\begin{array}{l}\text { i-gel } 3: 12 \\
\text { i-gel } 4: 12 \\
\text { i-gel } 5: 14\end{array}$ \\
\hline $\begin{array}{l}\text { First time } \\
\text { insertion suc- } \\
\text { cess rate }\end{array}$ & $76-100 \%(87.3 \%)$ & $86-100 \%$ ( $90 \%)$ & $>85 \%$ \\
\hline $\mathrm{OLP}\left(\mathrm{cm} \mathrm{H} \mathrm{H}_{2} \mathrm{O}\right)$ & $27-31$ & $26-30$ & $26-30$ \\
\hline
\end{tabular}

Table 1 and Figure 1(a-c): Gives a description of the three SADs and technical details [5-10].

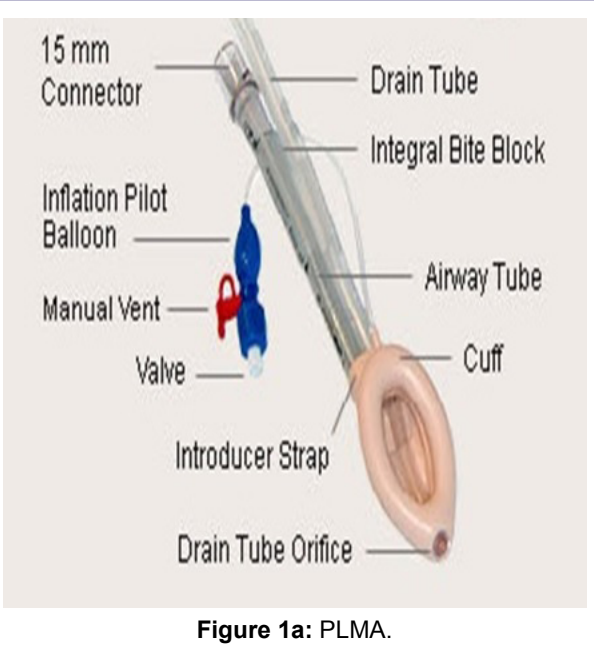




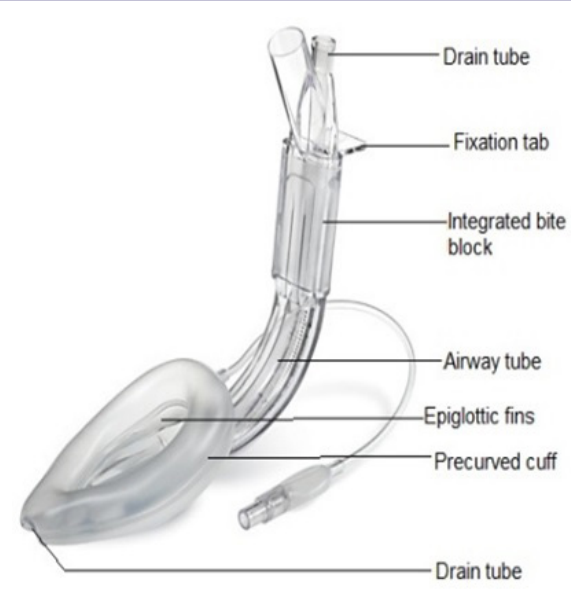

Figure 1b: SLMA.

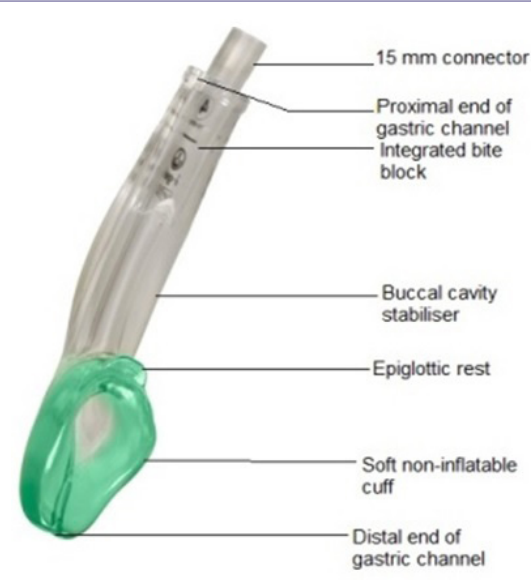

Figure 1c: i-gel.

\section{Ease of insertion}

The SAD may be inserted using the standard (finger guided), introducer guided or gastric tube guided techniques. The bougie guided technique of PLMA had the highest success rate of $100 \%$ in comparison with the other methods of PLMA insertion [11]. All the three SADs devices had a $100 \%$ success rate of insertion in three attempts [8]. The insertion characteristics depend on the cuff size and design, method of insertion and the chosen end point for insertion time (insertion of device, connection to circuit, effective ventilation or satisfactory capnograph).

\section{Oropharyngeal Leak Pressure (OLP)}

The OLP depends on the method used to measure it. However all the 4 methods namely, detection of leak by auditory, auscultatory or capnographic method and manometric stabilisation have been shown to correlate [12]. The OLP in all the three devices PLMA, SLMA and i-gel are similar and in the range $25-30 \mathrm{~cm} \mathrm{H}_{2} \mathrm{O}$ with a cuff inflation pressure of $60 \mathrm{~cm} \mathrm{H}_{2} \mathrm{O}$ [8].

\section{Drain tube}

The second generation SADs has a drain tube which separates the alimentary and respiratory tracts. The diameter and position of this drain tube influences the ease of insertion of gastric tube. The PLMA and SLMA have a wider bore drain tube that forms a better esophageal seal; thus these devices should theoretically offer greater protection against aspiration than i-gel. The i-gel has a narrower drain tube though the manufacturer claims it offers enough esophageal seal. The esophagus forms a continuous tract with this drain tube. The ease of insertion of gastric tube was easier in SLMA as well as i-gel than in PLMA though the success of insertion was similar [13,14].

\section{Pathophysiology of pneumoperitoneum and anesthetic concerns with use of SAD}

Laparoscopic surgery requires creation of pneumoperitoneum and appropriate positioning to facilitate intra-abdominal visualization and surgical access. Several studies have established the safety of LMA in patients with normal respiratory compliance and airway pressure $\left(\mathrm{Paw}<20 \mathrm{~cm} \mathrm{H}_{2} \mathrm{O}\right)$ [15]. Both these variables are affected in LS. The cardiovascular effects are more pronounced in the reverse Trendlenberg position while the respiratory embarrassment is more in the Trendlenberg (head down) position. There is a 30-50\% decrease in thoraco-pulmonary compliance, increase in Paw and Pmean, decrease in FRC, V-Q mismatch and intra-operative basal atelectasis due to elevation of the diaphragm [16]. Maintenance of Intra-abdominal Pressure (IAP) $<15 \mathrm{~mm} \mathrm{Hg}$ and change in position between 15-20 has only minimal effects on non-obese and those without cardiac problems [17].

The level of airway protection afforded by the SAD is the interplay of several factors. Studies show decreased LES tone with the use of supraglottic airway device but no effect on the pharyngo-esophageal reflux $[18,19]$. The increase in IAP during LS may cause reflux of gastric contents with the risk of regurgitation or pulmonary aspiration [20]. However, it has been also revealed that the increase in IAP may induce an adaptive response in the LES that allows maintenance of pressure gradient across the gastro esophageal junction and may actually reduce the risk of regurgitation [21]. Further the head down position used in pelvic laparoscopy may be protective in preventing regurgitated fluid from entering the airway [16].

Evans et al., demonstrated the effective isolation of the respiratory and gastrointestinal tracts by the PLMA in paralyzed and non paralyzed patients [22]. Cadaver models have shown that Proseal LMA protects against regurgitation and aspiration by effective separation of the pharynx and larynx [23]. Bernandini et al., retrospectively analyzed the risk of pulmonary aspiration in 65712 procedures under general anaesthesia with positive pressure ventilation [24]. This included 35,360 surgeries under LMA, 2.4\% of these being laparoscopic. There were three cases of pulmonary aspiration in the LMA group, none of them underwent LS. The major risk factor for aspiration was unplanned surgery. The low incidence of aspiration in the LMA group ( 1 in 11877) may be attributed to fewer LMA usages in emergency surgery. However, to reveal a true difference in aspiration risk between LMA and ETT, the number of patients needed to be studied is much larger (approximately fifty times greater). There have been case reports on the accidental aspiration of esophageal contents during the use of PLMA as well as i-gel $[25,26]$. In these cases, aspiration may have occurred due to mal positioning, stomach inflation due to air leak, unfamiliarity with the device or inappropriate patient selection.

\section{SAD in laparoscopic cholecystectomy}

Laparoscopic cholecystectomy is often conducted as day surgery [27]. The surgery involves creation of pneumoperitoneum and a 


\begin{tabular}{|c|c|c|c|c|c|c|}
\hline Study & Participants & Intervention(s) & Outcome(s) & OLP $\left(\mathrm{cm} \mathrm{H}_{2} \mathrm{O}\right)$ & $\begin{array}{l}\text { Paw (after pneu- } \\
\text { moperitoneum) } \\
\left(\mathrm{cm} \mathrm{H} \mathrm{H}_{2} \mathrm{O}\right)\end{array}$ & Remarks \\
\hline $\begin{array}{l}\text { Maltby et al., } \\
\text { [31] }\end{array}$ & $\begin{array}{c}109 \text { ASA I-III adults } \\
\text { including obese patients } \\
\text { (BMI>30 kg/m2) undergo- } \\
\text { ing LC }\end{array}$ & $\begin{array}{c}\text { Prospective randomised } \\
\text { trial to compare PLMA } \\
\text { with ETT }\end{array}$ & $\begin{array}{c}\text { Ventilation parameters, gastric } \\
\text { distension, respiratory events at } \\
\text { extubation }\end{array}$ & & $\begin{array}{l}\text { PLMA : } 25 \\
\text { ETT : } 25\end{array}$ & $\begin{array}{l}\text { PLMA and ETT equally } \\
\text { effective in non obese. } \\
4 \text { obese patients } \\
\text { crossed over to ETT. }\end{array}$ \\
\hline $\begin{array}{c}\text { Gulec et al., } \\
\text { [33] }\end{array}$ & $\begin{array}{l}63 \text { ASA I-II non obese pa- } \\
\text { tients, aged between } 20-70 \\
\text { years scheduled for LC }\end{array}$ & $\begin{array}{l}\text { Prospective randomized } \\
\text { trial to compare PLMA } \\
\text { and ETT }\end{array}$ & $\begin{array}{c}\text { Hemodynamic and respiratory } \\
\text { parameters, plasma adrenalin, } \\
\text { noradrenalin, dopamine and } \\
\text { cortisol levels }\end{array}$ & & & $\begin{array}{l}\text { PLMA produces less } \\
\text { metabolic stress, } \\
\text { cortisol levels higher in } \\
\text { ETT than PLMA }\end{array}$ \\
\hline Lu et al., [4] & $\begin{array}{l}80 \text { anaesthetized, para- } \\
\text { lyzed patients (ASA 1-2, } \\
\text { aged } 18-80 \text { yr) undergoing } \\
\text { LC }\end{array}$ & $\begin{array}{c}\text { Prospective randomized } \\
\text { trial to compare PLMA } \\
\text { with CLMA }\end{array}$ & $\begin{array}{l}\text { Ease of insertion, OLP, peak } \\
\text { airway pressure, oxygenation } \\
\text { and ventilation, adverse events }\end{array}$ & $\begin{array}{l}\text { PLMA : } 29 \\
\text { CLMA : } 19\end{array}$ & $\begin{array}{l}\text { PLMA : } 24 \\
\text { CLMA : } 22\end{array}$ & $\begin{array}{l}\text { Use of CLMA } \\
\text { for laparoscopic } \\
\text { cholecystectomy not } \\
\text { recommemded }\end{array}$ \\
\hline $\begin{array}{l}\text { Hosten et al., } \\
\text { [13] }\end{array}$ & $\begin{array}{l}60 \text { non-obese adult pa- } \\
\text { tients undergoing LC }\end{array}$ & $\begin{array}{c}\text { Prospective randomized } \\
\text { trial to compare SLMA } \\
\text { with PLMA }\end{array}$ & $\begin{array}{l}\text { OLP, insertion success rates, } \\
\text { insertion times, degree of } \\
\text { gastric distension, intra- and } \\
\text { post-operative adverse events, } \\
\text { and hemodynamic and respira- } \\
\text { tory response }\end{array}$ & $\begin{array}{l}\text { PLMA : } 27 \\
\text { SLMA : } 27.8\end{array}$ & & $\begin{array}{l}\text { Both are effective. } \\
\text { Shorter device and } \\
\text { drain tube insertion } \\
\text { time with SLMA }\end{array}$ \\
\hline $\begin{array}{l}\text { Belena et al., } \\
\text { [34] }\end{array}$ & $\begin{array}{c}120 \text { non obese ASA } 1-3 \\
\text { patients age }>18 \text { years } \\
\text { undergoing LC }\end{array}$ & $\begin{array}{l}\text { Prospective, sin- } \\
\text { gle-blind, randomised, } \\
\text { controlled study to } \\
\text { compare SLMA with } \\
\text { PLMA }\end{array}$ & $\begin{array}{l}\text { OLP, time and number of } \\
\text { attempts for insertion, ease of } \\
\text { drain tube insertion, adequacy } \\
\text { of ventilation and the incidence } \\
\text { of complication }\end{array}$ & $\begin{array}{l}\text { PLMA : } 30.7 \\
\text { SLMA : } 26.8\end{array}$ & & $\begin{array}{l}\text { SLMA higher success } \\
\text { first attempt insertion } \\
\text { rate, PLMA higher } \\
\text { OLP and tidal volume } \\
\text { achieved }\end{array}$ \\
\hline $\begin{array}{l}\text { Natalini et al., } \\
\text { [32] }\end{array}$ & $\begin{array}{c}60 \text { adult ASA physical } \\
\text { status I, II, and III patients } \\
\text { undergoing various laparo- } \\
\text { scopic surgery }\end{array}$ & $\begin{array}{l}\text { Prospective, controlled, } \\
\text { randomized, non-blind- } \\
\text { ed clinical study to } \\
\text { compare PLMA with } \\
\text { CLMA }\end{array}$ & $\begin{array}{l}\text { Heart rate, arterial pressure, } \\
\text { inspiratory and expiratory } \vee(\mathrm{T}) \text {, } \\
\text { airway pressure, } \mathrm{ETCO}_{2} \text { and } \\
\mathrm{SpO}_{2}\end{array}$ & $\begin{array}{l}\text { PLMA : } 23.5 \\
\text { CLMA : } 22.9\end{array}$ & & $\begin{array}{c}\text { PLMA and the LMA } \\
\text { show similar airtight } \\
\text { efficiency }\end{array}$ \\
\hline $\begin{array}{c}\text { Sharma et al., } \\
{[35]}\end{array}$ & $\begin{array}{l}60 \text { ASA I-II adult non } \\
\text { obese patients scheduled } \\
\text { for LC }\end{array}$ & $\begin{array}{l}\text { Prospective randomized } \\
\text { comparative study to } \\
\text { compare PLMA and } \\
\text { i-gel }\end{array}$ & OLP, respiratory mechanics & $\begin{array}{l}\text { PLMA : } 38.9 \\
\text { I-GEL : } 35.6\end{array}$ & & $\begin{array}{l}\text { PLMA better seal, } \\
\text { ventilation of both } \\
\text { comparable, malrota- } \\
\text { tion greater with i-gel }\end{array}$ \\
\hline Cha et al., [36] & $\begin{array}{l}124 \text { anesthetized, para- } \\
\text { lyzed patients ASA } 1 \text { to } \\
\text { 2; aged, } 18 \text { to } 80 \text { years } \\
\text { undergoing LC }\end{array}$ & $\begin{array}{c}\text { Prospective randomized } \\
\text { trial to compare SLIPA } \\
\text { with PLMA }\end{array}$ & $\begin{array}{l}\text { Gastric distension, fibre-optic } \\
\text { view of glottis opening, sore } \\
\text { throat }\end{array}$ & & & $\begin{array}{c}\text { SLIPA is as efficacious } \\
\text { as PLMA }\end{array}$ \\
\hline $\begin{array}{c}\text { Chung et al., } \\
\text { [37] }\end{array}$ & $\begin{array}{l}120 \text { ASA physical status } \\
\text { I-Il patients, aged } 18-65 \\
\text { yrs scheduled for LC }\end{array}$ & $\begin{array}{l}\text { Prospective randomized } \\
\text { non blinded trial to com- } \\
\text { pare PLMA with Cobra } \\
\text { perilaryngeal airway }\end{array}$ & $\begin{array}{l}\text { Insertion characteristics, } \\
\text { airway adequacies, ventilation } \\
\text { efficacies, degrees of gastric } \\
\text { distension, and postoperative } \\
\text { adverse events }\end{array}$ & $\begin{array}{c}\text { Cobra PLA : } \\
28.3 \\
\text { PLMA : } 29.4\end{array}$ & $\begin{array}{l}\text { Cobra PLA : } 22.4 \\
\text { PLMA : } 21.6\end{array}$ & Both are comparable \\
\hline $\begin{array}{c}\text { Sharma et al., } \\
\text { [38] }\end{array}$ & $\begin{array}{l}100 \text { patients of physical } \\
\text { status ASA I - III, aged } \\
18-85 \text { years of either sex, } \\
\text { scheduled for various } \\
\text { elective laparoscopic } \\
\text { procedures }\end{array}$ & $\begin{array}{l}\text { Prospective observa- } \\
\text { tional study to evaluate } \\
\text { the PLMA as a ventila- } \\
\text { tory device }\end{array}$ & $\begin{array}{l}\text { haemodynamic responses to in- } \\
\text { sertion, ventilatory parameters, } \\
\text { ease of gastric tube placement, } \\
\text { gastric insufflation and postop- } \\
\text { erative complication }\end{array}$ & 28.04 & 24.74 & $\begin{array}{l}\text { PLMA is a safe airway } \\
\text { device Removal of } \\
\text { gastric fluid is nec- } \\
\text { essary }\end{array}$ \\
\hline $\begin{array}{l}\text { Maharjan et } \\
\text { al., [39] }\end{array}$ & $\begin{array}{c}60 \text { patients who underwent } \\
\text { LC }\end{array}$ & $\begin{array}{l}\text { Prospective randomized } \\
\text { study to compare the } \\
\text { laryngeal seal of i-gel } \\
\text { vs ETT }\end{array}$ & $\begin{array}{l}\text { Airway pressure, } \mathrm{ETCO}_{2}, \mathrm{SpO}_{2} \\
\text { Inhaled and exhaled tidal } \\
\text { volume, minute volume, leak } \\
\text { volume and leak fraction }\end{array}$ & & $\begin{array}{l}\text { I-GEL : } 20.21 \\
\text { ETT : } 20.55\end{array}$ & $\begin{array}{l}\text { i-gel suitable alterna- } \\
\text { tive to ett }\end{array}$ \\
\hline $\begin{array}{l}\text { Saraswat et } \\
\text { al., [40] }\end{array}$ & $\begin{array}{l}60 \text { non-obese ASA1-2 pa- } \\
\text { tients undergoing various } \\
\text { laparoscopic surgery }\end{array}$ & $\begin{array}{l}\text { Prospective randomized } \\
\text { study to compare the } \\
\text { efficacy of PLMA and } \\
\text { ETT }\end{array}$ & $\begin{array}{l}\text { Attempts and time taken for } \\
\text { insertion, haemodynamic } \\
\text { changes, oxygenation, venti- } \\
\text { lation and intraoperative and } \\
\text { postoperative laryngopharyn- } \\
\text { geal morbidity }\end{array}$ & PLMA : 35 & & $\begin{array}{l}\text { PLMA proved to be } \\
\text { a suitable and safe } \\
\text { alternative to ETT }\end{array}$ \\
\hline $\begin{array}{l}\text { Badheka et } \\
\text { al., [41] }\end{array}$ & $\begin{array}{l}60 \text { ASA physical status } \\
\text { I and II non-obese adult } \\
\text { patients undergoing vari- } \\
\text { ous elective laparoscopic } \\
\text { surgeries }\end{array}$ & $\begin{array}{l}\text { Prospective randomized } \\
\text { study to compare i-gel } \\
\text { as an alternative to } \\
\text { endotracheal tube }\end{array}$ & $\begin{array}{l}\text { Ease, attempts and time for } \\
\text { insertion, haemodynamic and } \\
\text { ventilatory parameters, gastric } \\
\text { tube insertion, and periopera- } \\
\text { tive complication }\end{array}$ & & & $\begin{array}{l}\text { i-gel requires less } \\
\text { time for insertion with } \\
\text { minimal hemodynamic } \\
\text { changes when com- } \\
\text { pared to ETT. }\end{array}$ \\
\hline Esa et al., [42] & $\begin{array}{l}54 \text { ASA1-2 non obese pa- } \\
\text { tients undergoing various } \\
\text { laparoscopic surgeries }\end{array}$ & $\begin{array}{l}\text { prospective randomized } \\
\text { study comparing Laryn- } \\
\text { geal Tube Suction II } I^{\mathrm{TM}} \\
\left(\mathrm{LTS} \mathrm{II}^{\mathrm{TM}}\right) \text { with PLMA }\end{array}$ & $\begin{array}{l}\text { ease of insertion, haemo- } \\
\text { dynamic changes, quality of } \\
\text { airway seal, oxygenation and } \\
\text { ventilation parameters and } \\
\text { complication }\end{array}$ & $\begin{array}{l}\text { LTSII : } 33.6 \\
\text { PLMA : } 35.7\end{array}$ & $\begin{array}{l}\text { LTSII : } 20.6 \\
\text { PLMA : } 22\end{array}$ & $\begin{array}{l}\text { clinical performance } \\
\text { of the LTS II }{ }^{\mathrm{TM}} \text { and } \\
\text { the PLMA }{ }^{\mathrm{TM}} \text { was } \\
\text { comparable }\end{array}$ \\
\hline
\end{tabular}




\begin{tabular}{|c|c|c|c|c|c|c|}
\hline $\begin{array}{l}\text { Kang et al., } \\
\text { [43] }\end{array}$ & $\begin{array}{l}98 \text { adult patients undergo- } \\
\text { ing various laparoscopic } \\
\text { procedures }\end{array}$ & $\begin{array}{c}\text { Prospective randomised } \\
\text { study, comparing effica- } \\
\text { cy and adverse events } \\
\text { among patients with low } \\
\text { (limiting } 25 \mathrm{~cm} \mathrm{H}_{2} \mathrm{O}, \mathrm{L} \\
\text { group) and high (at } 60 \\
\mathrm{~cm} \mathrm{H}_{2} \mathrm{O}, \mathrm{H} \text { group) LMA } \\
\text { cuff pressure groups } \\
\text { with SLMA }\end{array}$ & $\begin{array}{l}\text { Postoperative pharyngolaryn- } \\
\text { geal adverse events, safety and } \\
\text { efficacy of ventilating with low } \\
\text { cuff pressure }\end{array}$ & $\begin{array}{l}\text { L group : } 27.2 \\
\mathrm{H} \text { group : } 31.1\end{array}$ & $\begin{array}{l}\text { L group : } 17.0 \\
\text { H group : } 18.4\end{array}$ & $\begin{array}{l}\text { Low SLMA cuff } \\
\text { pressure allowed safe } \\
\text { airway management } \\
\text { with lower incidence of } \\
\text { postoperative pharyn- } \\
\text { golaryngeal adverse } \\
\text { events }\end{array}$ \\
\hline Jain et al., [44] & $\begin{array}{l}10 \text { non obese ASA } 1-2 \\
\text { patients undergoing LC }\end{array}$ & $\begin{array}{l}\text { Observational study } \\
\text { in anaesthetized } \\
\text { paralysed patients with } \\
\text { PLMA as airway device }\end{array}$ & $\begin{array}{c}\text { Pulse rate, systolic/diastolic/ } \\
\text { mean blood pressure, } \mathrm{EtCO}_{2} \\
\mathrm{SpO}_{2}, \mathrm{ABG}, \text { and peak airway } \\
\text { pressure }\end{array}$ & & 21.2 & $\begin{array}{l}\text { PLMA effective for ven- } \\
\text { tilation in laparoscopic } \\
\text { surgery provided } \\
\text { precautions to prevent } \\
\text { hypercarbia are taken }\end{array}$ \\
\hline $\begin{array}{l}\text { Kahla et al., } \\
\text { [30] }\end{array}$ & $\begin{array}{c}80 \text { ASA } 1-2 \text { patients under- } \\
\text { going various laparoscopic } \\
\text { surgery }\end{array}$ & $\begin{array}{c}\text { Prospective randomized } \\
\text { trial to compare SLMA } \\
\text { vs ETT }\end{array}$ & $\begin{array}{l}\text { Ease of insertion, OLP, gastric } \\
\text { insufflation, ventilator capability, } \\
\text { hemodynamic response }\end{array}$ & SLMA : 27.5 & $\begin{array}{l}\text { SLMA : } 22.7 \\
\text { ETT : } 18.7\end{array}$ & $\begin{array}{l}\text { SLMA and ETT were } \\
\text { comparable }\end{array}$ \\
\hline $\begin{array}{l}\text { Belena et al., } \\
\text { [28] }\end{array}$ & $\begin{array}{l}100 \text { ASA physical status } \\
1,2 \text {, and } 3 \text { adult patients } \\
\text { undergoing LC }\end{array}$ & $\begin{array}{l}\text { Prospective observa- } \\
\text { tional study to evaluate } \\
\text { the SLMA }\end{array}$ & $\begin{array}{l}\text { Ease of insertion of device and } \\
\text { drain tube, OLP, postoperative } \\
\text { sore throat, Stomach size }\end{array}$ & 28.8 & 22.9 & $\begin{array}{l}\text { SLMA is effective } \\
\text { ventilatory device for } \\
\text { laparoscopic cholecys- } \\
\text { tectomy }\end{array}$ \\
\hline $\begin{array}{l}\text { Aydogmus et } \\
\text { al., [45] }\end{array}$ & $\begin{array}{c}60 \text { ASA } 1 \text { patients under- } \\
\text { going various laparoscopic } \\
\text { surgeries }\end{array}$ & $\begin{array}{l}\text { Prospective observa- } \\
\text { tional study to examine } \\
\text { SLMA as airway device }\end{array}$ & $\begin{array}{l}\text { Hemodynamic response, } \\
\mathrm{EtCO}_{2} \text {, postoperative compli- } \\
\text { cations }\end{array}$ & & & $\begin{array}{l}\text { SLMA suitable } \\
\text { alternative to ETT in } \\
\text { laparoscopic surgery }\end{array}$ \\
\hline $\begin{array}{c}\text { Sharma et al., } \\
{[46]}\end{array}$ & $\begin{array}{l}1000 \text { consecutive patients } \\
\text { ASA } 1-3 \text {, including } 123 \\
\text { obese patients undergoing } \\
\text { various elective laparo- } \\
\text { scopic surgeries }\end{array}$ & $\begin{array}{l}\text { Descriptive study, non } \\
\text { randomized with PLMA } \\
\text { as airway device }\end{array}$ & $\begin{array}{l}\text { Details of insertion, OLP, } \\
\text { ventilatory performance and } \\
\text { safety data }\end{array}$ & 36 & 18 & PLMA effective in LS \\
\hline $\begin{array}{l}\text { Abdellatif et } \\
\text { al., [47] }\end{array}$ & $\begin{array}{l}120 \text { ASA1-2 patients } \\
\text { undergoing various laparo- } \\
\text { scopic surgeries }\end{array}$ & $\begin{array}{c}\text { Randomised controlled } \\
\text { trial comparing PLMA } \\
\text { and SLIPA }\end{array}$ & $\begin{array}{l}\text { Number of insertion attempts, } \\
\text { insertion time, ease of insertion, } \\
\text { and fiberoptic bronchoscopic } \\
\text { view, lung mechanics, postoper- } \\
\text { ative complications }\end{array}$ & $\begin{array}{l}\text { PLMA : } 28.2 \\
\text { SLIPA : } 27.1\end{array}$ & $\begin{array}{l}\text { PLMA : } 24.3 \\
\text { SLIPA : } 25.4\end{array}$ & $\begin{array}{l}\text { Both provide effective } \\
\text { ventilation. Greater } \\
\text { incidence of sore } \\
\text { throat with PLMA. } \\
\text { Blood on device more } \\
\text { with SLIPA. }\end{array}$ \\
\hline
\end{tabular}

reverse Trendlenberg position with lateral tilt. The Peak Airway Pressure (Paw) increases by 5-7 $\mathrm{cm} \mathrm{H}_{2} \mathrm{O}$ after carboperitoneum. The airway pressure after reverse Trendlenberg position did not differ significantly from that in the supine position [28].

Effective gastric decompression is desirable from the stage of trochar insertion till end of surgery to avoid injury to the stomach and interference with surgery. Gastric drainage is also required especially if an intra-operative cholangiogram is done as it usually increases the gastric output [29]. When the surgeon's assessment of gastric inflation after trochar insertion and at the end of surgery before removal of laparoscope was noted, it was comparable between PLMA, SLMA and endotracheal tube [13,28,30,31]. Maltby et al., found that this gastric inflation occurred even when the gastric tube was connected to a continuous suction throughout the procedure. This has been attributed to different angles of visualization rather than true distension. Kahla et al., inserted a gastric tube and removed it after suction while Hosten et al., connected the gastric tube to a collection bag. Belena et al., connected the gastric tube to a bag after initial suctioning for 10 second. In all these cases, the gastric inflation did not interfere with the surgery. The conventional and gold standard anesthesia technique for laparoscopic cholecystectomy is endotracheal intubation and controlled ventilation. However after extensive experience with gynaecologic laparoscopy and sterilization procedure, LMA has been attempted to be used, in non obese well fasted patients without GERD and having low risk of aspiration, for laparoscopic cholecystectomy. Lu et al., concluded that the CLMA is unsuitable for laparoscopic cholecystectomy [4]. The CLMA provided adequate ventilation before carboperitoneum but was associated with a high incidence of suboptimal and failed ventilation with abdominal insufflations to $15 \mathrm{~mm} \mathrm{Hg}$. The peak airway pressure after carboperitoneum was similar in both the groups $\left(24 \mathrm{~cm} \mathrm{H}_{2} \mathrm{O}\right.$ PLMA and 22 $\mathrm{cm} \mathrm{H}_{2} \mathrm{O}$ CLMA) but exceeded the OLP $\left(19 \mathrm{~cm} \mathrm{H}_{2} \mathrm{O}\right)$ in CLMA group and hence provided ineffective ventilation. Natalini et al., found the PLMA and CLMA comparable during usage in various LS. However, the authors increased the cuff pressure $>60 \mathrm{~cm} \mathrm{H}_{2} \mathrm{O}$ in several patients to facilitate ventilation through the SAD [32].

Table 2 gives the list of studies where a second generation has been used to secure the airway in Laparoscopic Cholecystectomy (LC) or various elective laparoscopic procedures.

The PLMA is the standard benchmark state of art second generation SAD with which any new SAD is compared [7]. Since its introduction in 2000, several studies have demonstrated the feasibility and efficiency of PLMA as an airway device in laparoscopic cholecystectomy. This includes eight prospective randomized trials comparing PLMA with other airway devices including ETT (two) [31,33], SLMA (two) [13, 34], cLMA (one) [4], i-gel (one) [35], SLIPA (one) [36] and Cobra peri-laryngeal airway (one) [37]. PLMA was found to be comparable with ETT in non-obese patients undergoing laparoscopic cholecystectomy [31,33]. In comparison with SLMA and i-gel, higher OLP was achieved with PLMA indicating better airway seal with this device. The SLMA was comparable with ETT in 80 patients undergoing laparoscopic surgery with no cases of failed ventilation or crossover from the SLMA group. The practicality of i-Gel use in laparoscopic cholecystectomy has been studied in two randomized trials. I-gel was found to be a workable alternative to ETT in LS in patients with normal airway pressures [39].

Single device studies have also been conducted to explore SAD use in various LS including laparoscopic cholecystectomy, appendectomy, 


\begin{tabular}{|c|c|c|c|c|c|c|}
\hline Study & Participants & Intervention(s) & Outcome(s) & $\mathrm{OLP}\left(\mathrm{cm} \mathrm{H}_{2} \mathrm{O}\right)$ & $\begin{array}{l}\text { Paw (after pneumo- } \\
\text { peritoneum) ( } \mathrm{cm} \\
\left.\mathrm{H}_{2} \mathrm{O}\right)\end{array}$ & Remarks \\
\hline $\begin{array}{l}\text { Maltby et al., } \\
{[48]}\end{array}$ & $\begin{array}{c}209 \text { women, ASA } \\
\text { physical status I-III, } \\
\text { including non-obese } \\
\text { (BMI } \leq 30 \mathrm{~kg} / \mathrm{m} 2) \\
\text { or obese }(\mathrm{BMl}>30 \\
\mathrm{kg} / \mathrm{m} 2)\end{array}$ & $\begin{array}{l}\text { Prospective random- } \\
\text { ized controlled trial to } \\
\text { compare the CLMA in } \\
\text { non-obese patients ( } \\
\text { BMI } \leq 30 \mathrm{~kg} / \mathrm{m} 2), \text { PLMA } \\
\text { in obese ( } \mathrm{BMI}>30 \mathrm{~kg} / \\
\mathrm{m} 2) \text { and }(\mathrm{ETT})\end{array}$ & $\begin{array}{l}\text { ventilation, change in } \\
\text { stomach size and emergence } \\
\text { outcomes }\end{array}$ & $\begin{array}{l}\text { CLMA : } 20 \\
\text { PLMA : } 30\end{array}$ & $\begin{array}{c}\text { Pneumoperitoneum } \\
\text { <15min Non-obese } \\
\text { CLMA : } 19 \text { ETT : } 21 \\
\text { Obese PLMA : } 29 \\
\text { ETT : } 28 \text { Pneumoperi- } \\
\text { toneum } \\
>15 \mathrm{~min} \\
\text { Non-obese CLMA : } 22 \\
\text { ETT : }: 22 \text { Obese } \\
\text { PLMA : } 33 \text { ETT : } 32\end{array}$ & $\begin{array}{c}\text { stomach size changes } \\
\text { during surgery were } \\
\text { not statistically signif- } \\
\text { icant Obese patients } \\
\text { with Paw }>\text { OLP also } \\
\text { had no gas leak during } \\
\text { ventilation }\end{array}$ \\
\hline Lim et al., [49] & $\begin{array}{c}\text { 180patients ASA } \\
\text { grade 1-2, aged } \\
18-80 \mathrm{y}\end{array}$ & $\begin{array}{l}\text { Prospective random- } \\
\text { ized study to test the } \\
\text { hypothesis that the } \\
\text { PLMA is superior to } \\
\text { ETT }\end{array}$ & $\begin{array}{l}\text { Time to achieve an effective } \\
\text { airway, ventilatory capability, } \\
\text { peak airway pressure before } \\
\text { and after pneumoperitone- } \\
\text { um, duration of surgery and } \\
\text { pneumoperitoneum and } \\
\text { haemodynamic responses }\end{array}$ & & & $\begin{array}{l}\text { PLMAAND ETT } \\
\text { COMPARABLE FOR } \\
\text { Gynaecologic Lapa- } \\
\text { roscopy }\end{array}$ \\
\hline $\begin{array}{l}\text { Hohlrieder et } \\
\text { al., [50] }\end{array}$ & $\begin{array}{l}100 \text { non obese } \\
\text { female patients (ASA } \\
\text { I-II, } 18-75 \text { years) }\end{array}$ & $\begin{array}{l}\text { Randomised double } \\
\text { blind prospective study } \\
\text { comparing ProSeal } \\
\text { LMA with ETT }\end{array}$ & $\begin{array}{l}\text { postoperative pain score, } \\
\text { morphine requirement,PONV }\end{array}$ & & & $\begin{array}{l}\text { pain and nausea } \\
\text { less in PLMA than } \\
\text { ETT group, no diff in } \\
\text { vomiting }\end{array}$ \\
\hline $\begin{array}{l}\text { Griffiths et al., } \\
{[51]}\end{array}$ & $\begin{array}{l}116 \text { non-obese } \\
\text { women }\end{array}$ & $\begin{array}{c}\text { Observer-blinded } \\
\text { randomised controlled } \\
\text { trial comparing PLMA } \\
\text { versus ETT }\end{array}$ & $\begin{array}{c}\text { postoperative pain score, } \\
\text { morphine consumption, eme- } \\
\text { sis and adverse upper airway } \\
\text { symptoms }\end{array}$ & & & $\begin{array}{l}\text { PLMA did not de- } \\
\text { crease pain or PONV } \\
\text { in comparison with } \\
\text { ETT }\end{array}$ \\
\hline Lee et al., [52] & 70 patients & $\begin{array}{l}\text { Prospective ran- } \\
\text { domised controlled } \\
\text { study comparing the } \\
\text { SLMA with PLMA }\end{array}$ & $\begin{array}{l}\text { OLP, ease of insertion, } \\
\text { adequacy of ventilation and } \\
\text { incidence of complications }\end{array}$ & $\begin{array}{l}\text { PLMA : } 31.7 \\
\text { SLMA : } 27.9\end{array}$ & & $\begin{array}{l}\text { SLMA had lower OLP } \\
\text { and lower achieved } \\
\text { Vte though not clinical- } \\
\text { ly significant, gastric } \\
\text { tube insertion easier } \\
\text { in SLMA }\end{array}$ \\
\hline $\begin{array}{l}\text { Jeon et al., } \\
\quad[53]\end{array}$ & $\begin{array}{l}30 \text { non obese women } \\
\text { ASA status } 1 \text { or } 2, \\
\text { aged } 18-65 \text { years, }\end{array}$ & $\begin{array}{l}\text { Prospective random- } \\
\text { ized study to compare } \\
\text { PLMA and i-gel }\end{array}$ & $\begin{array}{l}\text { Airway sealing pressure } \\
\text { before and during pneumo- } \\
\text { peritoneum, insertion time, } \\
\text { and gas exchange. }\end{array}$ & $\begin{array}{c}\text { (after insertion) } \\
\text { PLMA : } 25.9 \\
\text { I-GEL : } 24.3 \text { (after } \\
\text { pneumoperito- } \\
\text { neum) } \\
\text { PLMA : } 28.3 \\
\text { I-GEL : } 28.2\end{array}$ & $\begin{array}{l}\text { PLMA : } 25 \\
\text { I-GEL : } 24\end{array}$ & $\begin{array}{l}\text { I-GEL reliable alterna- } \\
\text { tive to PLMA }\end{array}$ \\
\hline Roth et al., [54] & 50 ASA 1-2patients & $\begin{array}{l}\text { prospective, random- } \\
\text { ized study to compare } \\
\text { PLMA and LTS. }\end{array}$ & $\begin{array}{l}\text { Ease of insertion, quality of } \\
\text { airway seal, risk of gastric in- } \\
\text { sufflation and patient comfort }\end{array}$ & $\begin{array}{l}\text { PLMA : } 45.4 \\
\text { LTS : } 45.6\end{array}$ & & $\begin{array}{l}\text { Both devices provide a } \\
\text { secure airway }\end{array}$ \\
\hline $\begin{array}{l}\text { Miller et al., } \\
\text { [55] }\end{array}$ & $\begin{array}{l}150 \text { non obese } \\
\text { patients }\end{array}$ & $\begin{array}{c}\text { Prospective random- } \\
\text { ized controlled trial to } \\
\text { compare the efficacy } \\
\text { of the ProSeal LMA } \\
\text { and SLIPATM with the } \\
\text { standard Tracheal } \\
\text { Tube (TT). The patients } \\
\text { receiving a SAD were } \\
\text { not paralysed }\end{array}$ & $\begin{array}{l}\text { Ease of use, quality of seal, } \\
\text { ventilation, systolic pressure, } \\
\text { response to intubation, side } \\
\text { effects and operating room } \\
\text { time }\end{array}$ & $\begin{array}{l}\text { PLMA : } 31 \\
\text { SLIPA : } 30\end{array}$ & $\begin{array}{l}\text { ETT : } 20.2 \\
\text { PLMA : } 21.3 \\
\text { SLIPA : } 22.6\end{array}$ & $\begin{array}{l}\text { ProSeal LMA and } \\
\text { SLIPA were easy to } \\
\text { use without requiring } \\
\text { muscle relaxants, } \\
\text { and reduce operating } \\
\text { roomtime compared } \\
\text { to the TT technique in } \\
\text { day case laparosco- } \\
\text { pies. }\end{array}$ \\
\hline Abdi et al., [56] & $\begin{array}{l}138 \text { elective pelvic } \\
\text { laparoscopic ASA I-II } \\
\text { female patients }\end{array}$ & $\begin{array}{c}\text { Prospective random- } \\
\text { ized single-blind study } \\
\text { to compare SLMA vs } \\
\text { ETT }\end{array}$ & $\begin{array}{l}\text { ventilation efficiency Anes- } \\
\text { thesia- and surgery-related } \\
\text { time, Post-operative pain and } \\
\text { pharyngolaryngeal morbidity }\end{array}$ & & & $\begin{array}{l}\text { LMA Supreme and } \\
\text { the ETT were equally } \\
\text { effective airways for a } \\
\text { routine gynecological } \\
\text { laparoscopy }\end{array}$ \\
\hline $\begin{array}{l}\text { Teoh et al., } \\
{[57]}\end{array}$ & $\begin{array}{l}100 \text { ASA1-2 non } \\
\text { obese female patients } \\
\text { for laparoscopic } \\
\text { surgery in the Trende- } \\
\text { lenburg position }\end{array}$ & $\begin{array}{l}\text { Prospective random- } \\
\text { ized trial to compare } \\
\text { the efficacy of i-gel with } \\
\text { LMA Supreme }\end{array}$ & $\begin{array}{l}\text { OLP, ease of insertion, } \\
\text { haemodynamic response and } \\
\text { time to insertion, efficacy in } \\
\text { controlled positive pressure } \\
\text { ventilation and complications } \\
\text { of use }\end{array}$ & $\begin{array}{l}\text { SLMA : } 26.4 \\
\text { I-GEL : } 25\end{array}$ & $\begin{array}{l}\text { SLMA : } 23.8 \\
\text { I-GEL : } 22.4\end{array}$ & $\begin{array}{l}\text { MORE TIME FOR DT } \\
\text { INSERTION in i-gel, } \\
\text { EASY DT INSERTION } \\
\text { IN 100\% SLMA VS } \\
78 \% \text { I-GEL Leak vol- } \\
\text { ume more in i-gel but } \\
\text { no difference in OLP }\end{array}$ \\
\hline $\begin{array}{l}\text { Suhitharan et } \\
\text { al., [58] }\end{array}$ & $\begin{array}{l}70 \text { non obese anes- } \\
\text { thetized paralyzed } \\
\text { patients }\end{array}$ & $\begin{array}{l}\text { Prospective random- } \\
\text { ized controlled trial } \\
\text { comparing the SLMA } \\
\text { with i-gel }\end{array}$ & $\begin{array}{l}\text { OLP, successful first attempt } \\
\text { insertion rates, time and ease } \\
\text { of the airway and gastric tube } \\
\text { insertion, leak fraction and } \\
\text { pharyngeal morbidity }\end{array}$ & $\begin{array}{l}\text { SLMA : } 25.9 \\
\text { i-gel : } 24.4\end{array}$ & $\begin{array}{l}\text { SLMA : } 23.3 \\
\text { i-gel : } 22.8\end{array}$ & $\begin{array}{c}\text { Greater time to DT } \\
\text { insertion and leak } \\
\text { fraction in i-gel but not } \\
\text { clinically significant. } \\
\text { Both effective airway } \\
\text { devices }\end{array}$ \\
\hline
\end{tabular}




\begin{tabular}{|c|c|c|c|c|c|c|}
\hline $\begin{array}{l}\text { Chattopadhyay } \\
\text { et al., [59] }\end{array}$ & $\begin{array}{l}90 \text { ASA } 1-2 \text { non- } \\
\text { obese patients }\end{array}$ & $\begin{array}{l}\text { Prospective random- } \\
\text { ized trial to compare } \\
\text { SLMA vs i-gel }\end{array}$ & $\begin{array}{l}\text { OLP, insertion characteristics, } \\
\text { complications }\end{array}$ & $\begin{array}{l}\text { SLMA : } 24.4 \\
\text { i-gel : } 23.6\end{array}$ & $\begin{array}{l}\text { SLMA : } 23.4 \\
\text { i-gel : } 22.5\end{array}$ & $\begin{array}{l}\text { Both are effective for } \\
\text { ventilation. Gastric } \\
\text { tube insertion easier } \\
\text { in SLMA. Lesser sore } \\
\text { throat with i-gel }\end{array}$ \\
\hline $\begin{array}{l}\text { Chen et al., } \\
\text { [60] }\end{array}$ & $\begin{array}{c}120 \text { adult, ASA } \\
\text { physical status } 1 \text { and } \\
2 \text { women, aged } 18 \text { to } \\
55 \text { years. }\end{array}$ & $\begin{array}{l}\text { Prospective, ran- } \\
\text { domized study to test } \\
\text { the hypothesis that } \\
\text { muscle relaxant is not } \\
\text { necessary in patients } \\
\text { undergoing laparoscop- } \\
\text { ic gynecological surgery } \\
\text { with a PLMA }\end{array}$ & $\begin{array}{l}\text { Peak airway inflation } \\
\text { pressures, airway sealing } \\
\text { pressure, minimum flow rate, } \\
\text { and recovery time, Surgical } \\
\text { conditions, sore throat }\end{array}$ & $\begin{array}{l}\text { No muscle relax- } \\
\text { ant : } 32 \text { Muscle } \\
\text { relaxant : } 31\end{array}$ & & $\begin{array}{c}\text { Shorter recovery time } \\
\text { with no relaxant. Low } \\
\text { flows possible with no } \\
\text { relaxant }\end{array}$ \\
\hline $\begin{array}{c}\text { Belena et al., } \\
\text { [61] }\end{array}$ & $\begin{array}{c}140 \text { ASA } 1-2 \text { female } \\
\text { patients }\end{array}$ & $\begin{array}{l}\text { Prospective observa- } \\
\text { tional study evaluating } \\
\text { use of SLMA }\end{array}$ & $\begin{array}{c}\text { ease of insertion of the device } \\
\text { and the drain tube, OLP, } \\
\text { incidence of postoperative } \\
\text { sore throat, and other adverse } \\
\text { events }\end{array}$ & 28.2 & 22 & $\begin{array}{c}\text { Included } 5 \text { obese } \\
\text { patients with BMI }>35 \\
\mathrm{~kg} / \mathrm{m} 2, \text { SLMA safe and } \\
\text { efficacious in standard } \\
\text { cohort, }\end{array}$ \\
\hline $\begin{array}{l}\text { Mukkader et } \\
\text { al., [62] }\end{array}$ & 105 ASA $1-2$ patients & $\begin{array}{l}\text { Prospective random- } \\
\text { ized trial to compare } \\
\text { PLMA, SLMA and i-gel }\end{array}$ & OLP, airway morbidity & $\begin{array}{c}\text { PLMA : } 23.9 \\
\text { SLMA : } 24.9 \\
\text { i-gel : } 21 \\
\text { OLP after } 30 \text { min } \\
\text { PLMA : } 25 \\
\text { SLMA : } 25 \\
\text { i-gel : } 28.3\end{array}$ & $\begin{array}{l}\text { PLMA : } 21.4 \\
\text { SLMA : } 21.3 \\
\text { i-gel : } 21.37\end{array}$ & $\begin{array}{l}\text { initial OLP obtained by } \\
\text { i-gel were lower than } \\
\text { proseal and supreme, } \\
\text { but increased over } \\
\text { time. Ease of place- } \\
\text { ment best for i-gel }\end{array}$ \\
\hline
\end{tabular}

Table 3: SAD use in gynaecological laparoscopic surgery.

inguinal herniorraphy, incisional hernia repair and gynaecological laparoscopy. The PLMA proved to be an effective ventilatory device in LS. There was only a single case of failed ventilation after carboperitoneum that was managed by changing to CLMA. There were three cases of regurgitation through the drain tube though no incidence of aspiration and gastric drainage was recommended by the authors. The authors stress on the experience of the user before habitual use in LS and a low threshold for switchover to an alternative device in the event of SAD malfunction [38].

Use of SAD in laparoscopic cholecystectomy also provides several other benefits. These include decreased hemodynamic stress, improved emergence characteristics like less cough, sore throat and dysphagia. Decreased PONV and post operative opiate consumption has also been reported but larger numbers have to be studied to prove this benefit $[31,33,45]$.

\section{SAD in gynaecological laparoscopy}

Gynaecological laparoscopy was the earliest laparoscopic procedure to have an LMA inserted as the preferred airway device.

The usual gynaecological laparoscopic procedures are tubal ligation, diagnostic laparoscopy, hysterectomy, myomectomy and oophrectomy. It requires a Trendlenberg position of around $15^{\circ}$ and lithotomy. All the three devices - PLMA, SLMA and i-gel have been used in gynaecological laparoscopy and the results are tabulated in table 3 .

The effectiveness of SAD use in gynaecological surgery may be attributed to the short and elective nature of surgery, limitation of pneumoperitoneum and positioning to acceptable limits and the advantages offered by SAD in ambulatory surgery. Brimmacombe and Brain suggested "rule of 15 " in guiding CLMA use in LS that is Trendlenberg tilt $\leq 15^{\circ} \mathrm{Pabd} \leq 15 \mathrm{~cm} \mathrm{H}_{2} \mathrm{O}$ and peritoneal insufflation duration $\leq 15$ minutes. While the first two hold true, it is now known that the suitability of the SAD in LS will be evident in the first 15 minutes and will continue to prove effective provided adequate anaesthetic depth and muscle relaxation is maintained and the SAD is not dislodged [48]. There are 9 randomized trials comparing PLMA with various other airway devices in laparoscopic gynaecological surgery. This includes comparison with ETT (4) and one each with SLMA, i-gel, LTS and Cobra PLA and one comparing PLMA, SLMA and i-gel $[48-55,62]$. The PLMA had equivalent functionality with ETT. The SLMA and i-gel were also comparable with PLMA. The differences in OLP and leak volume did not prove to be clinically relevant. Hohlrieder et al., found decreased analgesic requirement, pain scores and nausea with PLMA while Griffiths et al., found no difference in a similar group. Comparison of SLMA with i-gel has shown similar ventilator efficacy $[50,51]$.

One point to note is that all patients were females and the results may not be extrapolated to males undergoing pelvic surgery in a similar position. Most of the studies have excluded obese women. Those which have included them found no difficulty in using SAD in obese patients $[48,61]$. The numbers however are small and no definitive conclusion may be made on their safety or efficacy in this cohort of patients.

\section{SAD in paediatric laparoscopic surgery}

The common laporoscopic surgical procedures in children include hernia repair, appendicectomy, cholecystectomy, orchiopexy and diagnostic laparoscopy. The cardiopulmonary effect of peritoneal insufflation in children is similar to that in adults but the effects are more pronounced at abdominal pressure of $12 \mathrm{~mm} \mathrm{Hg}$ with significant decrease in cardiac output, increase in systemic vascular resistance compared to Pabd of $6 \mathrm{~mm} \mathrm{Hg} \mathrm{[63].}$

Sinha and colleagues found the PLMA to have comparable ventilatory efficacy as ETT in short duration ( $<60 \mathrm{~min}$ ) laparoscopic procedures in children aged 6 months to 8 years. The mean OLP was $29 \mathrm{~cm} \mathrm{H}_{2} \mathrm{O}$ and Paw after carboperitoneum was $23.79 \mathrm{~cm} \mathrm{H}_{2} \mathrm{O}$ [64]. In a descriptive study, Dave and colleagues successfully used PLMA for ventilating 30 children during LS lasting $<60 \mathrm{~min}$. In two patients, it required changeover to ETT due to suboptimal ventilation [65].

The literature and experience on second generation SAD use in paediatric laparoscopy is still insufficient to recommend its use. Hence its use, if at all should be restricted to brief laparoscopic procedures or examination of the abdomen with Pabd kept $\leq 10 \mathrm{~mm} \mathrm{Hg}$. 


\section{SAD in the obese patient}

Alteration in respiratory mechanics, increased airway resistance and greater incidence of gastroesophageal reflux are the main concerns in choosing SAD as an airway device in obese patients. The advantages are decreased hemodynamic response during insertion and removal. They could also prove to be a valuable rescue device in difficult mask ventilation or intubation. A properly placed PLMA has been shown to provide good oxygenation, and reduce postoperative cough though inadequate information exists to comment on its ventilatory capabilities or vouch for its safety in obese patients undergoing routine or laparoscopic surgery [66].

Carron $\mathrm{M}$ et al., compared the hemodynamic and hormone stress response of PLMA and ETT in 70 morbidly obese pts (BMI > $30 \mathrm{~kg} / \mathrm{m}^{2}$ ) for laparoscopic banding surgery [67]. The study showed that there was significantly less hemodynamic and hormonal stress response with PLMA compared to ETT. The use of PLMA also showed reduction in the requirement for non-depolarizing muscle relaxant (ciastracurium) during surgery and oxygen de-saturation, pain and PONV scores in the postoperative recovery. In using an SAD for gastric banding, the use of a gastric tube rather than the usual balloon should be acceptable to the surgeon. Another point of concern is the use of PLMA for surgeries where postoperative gastric drainage is needed as the PLMA does not allow gastric drainage after its removal.

\section{Ventilation with SAD in laparoscopic surgery}

A ventilatory strategy that provides adequate oxygenation and ventilation in the face of increased airway pressure and resistance and decreased airway compliance is required during laparoscopic surgery. This is usually achieved with Volume Controlled Ventilation (VCV) with an increase in respiratory rate to increase the minute ventilation by around $20 \%$ after generation of the pneumoperitoneum. Pressure Controlled Ventilation (PCV) is associated with increased flow rates, faster achievement of tidal volume and lower peak airway pressure [53]. With an SAD in situ, it is necessary to ensure that the peak inspiratory pressure not exceed the oropharyngeal leak pressure. Jeon et al., found lower peak airway pressures and $\mathrm{PaCO}_{2}$ with PCV in patients undergoing laparoscopic gynaecological procedures with PLMA [53].

Carron et al., were able to achieve adequate gas exchange with PCV and I:E ratio of 1:1 in obese patients undergoing gastric banding while ventilating through a PLMA [67]. No hemodynamic instability was noted in any of these studies during PCV.

Low fresh gas flow is associated with reduced anaesthetic gas exposure, improved costs, conservation of heat and humidity. The use of supraglottic airway device may be associated with greater gas leakage than the endotracheal tube. However, both low flow (Fresh gas flow $<11 / \mathrm{min}$ ) and minimal flow (FGF $<0.51 / \mathrm{min}$ ) have been used with controlled ventilation in a properly positioned LMA during laparoscopic surgery $[48,60]$. Several workers have reported the Leak Fraction (LF) using SAD in LS $[32,39,57,58]$. The LF is the difference between the inspired and expired tidal volume divided by the inspired tidal volume expressed as a percentage. A leak fraction of $>15 \%$ is usually considered significant.

\section{Limitations}

There is a lot of heterogeneity with regard to SAD use in LS, in terms of experience of the user, type of device, method of insertion, nature of surgery, extent of pneumoperitoneum and positioning and mode of ventilation. Further, these studies are single blinded as it is not possible to blind the personnel using the device and recording the outcome. These issues need to be addressed in a meta-analysis.

\section{Conclusion}

Safety and efficacy are the critical factors that would define SAD use in LS. While efficacy has been demonstrated in several studies, protection against pulmonary aspiration is not guaranteed.

It must be understood that the success of SAD use in LS depends on the selection of the right cohort of patients and limiting pneumoperitoneum and positioning to acceptable limits. The key to successful use of SAD in laparoscopic surgery is insertion by an experienced user, ensuring correct position by clinical methods or fibre-optic bronchoscopy and the use of neuromuscular blockade and controlled ventilation. It is suggested that first time users gain reasonable expertise in short duration simple laparoscopic procedures like tubal ligation or diagnostic gynaecological laparoscopy before attempting their usage in other laparoscopic surgeries.

\section{References}

1. Brain Al (1983) The laryngeal mask--a new concept in airway management $\mathrm{Br} \mathrm{J}$ Anaesth 55: 801-805.

2. Verghese C, Brimacombe JR (1996) Survey of laryngeal mask airway usage in 11,910 patients: safety and efficacy for conventional and nonconventional usage. Anesth Analg 82: 129-133.

3. Timmermann A (2011) Supraglottic airways in difficult airway management: successes, failures, use and misuse. Anaesthesia 66: 45-56.

4. Lu PP, Brimacombe J, Yang C, Shyr M (2002) ProSeal versus the Classic laryngeal mask airway for positive pressure ventilation during laparoscopic cholecystectomy. Br J Anaesth 88: 824-827.

5. Cook TM, Lee G, Nolan JP (2005) The ProSeal laryngeal mask airway: a review of the literature. Can J Anaesth 52: 739-760.

6. Intavent Orthofix Ltd. (2007) The LMA Supreme ${ }^{T M}$ - Instruction Manual. Maidenhead, Intavent Orthofix Ltd., USA.

7. Wong DT, Yang JJ, Jagannathan N (2012) Brief review: The LMA Supreme ${ }^{T M}$ supraglottic airway. Can J Anesth 59: 483-493.

8. Cook T, Howes B (2011) Supraglottic airway devices: recent advances. Contin Educ Anaesth Crit Care Pain 11: 56-61.

9. Intersurgical Ltd. (2007) Intersurgical i-gel User Guide. Intersurgical Ltd. Wokingham, Berkshire, UK.

10. LMA ProSeal ${ }^{\circledR}$ (2002) Instruction manual. Intavent Limited, USA.

11. Brimacombe J, Keller C, Judd DV (2004) Gum elastic bougie-guided insertion of the ProSeal laryngeal mask airway is superior to the digital and introducer tool techniques. Anesthesiology 100: 25-29.

12. Keller C, Brimacombe JR, Keller K, Morris R (1999) Comparison of four methods for assessing airway sealing pressure with the laryngeal mask airway in adult patients. Br J Anaesth 82: 286-287.

13. Tulay Hoșten T, Yıldız TS, Kuș A, Solak M, Toker K (2012) Comparison of Supreme Laryngeal Mask Airway and ProSeal Laryngeal Mask Airway during Cholecystectomy. Balkan Med J 29: 314-319.

14. Singh I, Gupta M, Tandon M (2009) Comparison of Clinical Performance of I-Gel with LMA-Proseal in Elective Surgeries. Indian J Anaesth 53: 302-305.

15. Devitt JH, Wenstone R, Noel AG, O'Donnell MP (1994) The laryngeal mask airway and positive-pressure ventilation. Anesthesiology 80: 550-555.

16. Gerges FJ, Kanazi GE, Jabbour-Khoury SI (2006) Anesthesia for laparoscopy: a review. J Clin Anesth 18: 67-78. 
17. Joris JL (2010) Anesthesia for laparoscopic surgery. In: Miller RD (ed.). Miller's Anesthesia. (7thedn), Churchill Livingstone, Elsevier, London, UK.

18. Son Y, Park SK, Cheong YP, Choi YS, Ahn JY, et al. (2002) Effect of laryngeal mask airway on esophageal motility during general anesthesia. J Clin Anesth 14: 518-523.

19. Rabey PG, Murphy PJ, Langton JA, Barker P, Rowbotham DJ (1992) Effect of the laryngeal mask airway on lower oesophageal sphincter pressure in patients during general anaesthesia. Br J Anaesth 69: 346-348.

20. Perrin M, Fletcher A (2004) Laparoscopic abdominal surgery. Contin Educ Anaesth Crit Care Pain 4: 107-110.

21. Jones MJ, Mitchell RW, Hindocha N (1989) Effect of increased intra-abdominal pressure during laparoscopy on the lower esophageal sphincter. Anesth Analg 68: 63-65.

22. Evans NR, Gardner SV, James MF (2002) ProSeal laryngeal mask protects against aspiration of fluid in the pharynx. $\mathrm{Br} \mathrm{J}$ Anaesth 88: 584-587.

23. Schmidbauer W, Bercker S, Volk T, Bogusch G, Mager G, et al. (2009) Oesophageal seal of the novel supralaryngeal airway device I-Gel in comparison with the laryngeal mask airways Classic and ProSeal using a cadaver model. $\mathrm{Br} \mathrm{J}$ Anaesth 102: 135-139.

24. Bernardini A, Natalini G (2009) Risk of pulmonary aspiration with laryngea mask airway and tracheal tube: analysis on 65712 procedures with positive pressure ventilation. Anaesthesia 64: 1289-1294.

25. Brimacombe J, Keller C (2003) Aspiration of gastric contents during use of a ProSeal laryngeal mask airway secondary to unidentified foldover malposition. Anesth Analg 97:1192-1194.

26. Gibbison B, Cook TM, Seller C (2008) Case series: Protection from aspiration and failure of protection from aspiration with the i-gel airway. $\mathrm{Br} \mathrm{J}$ Anaesth 100: $415-417$.

27. Jain PK, Hayden JD, Sedman PC, Royston CM, O’Boyle CJ (2005) A prospective study of ambulatory laparoscopic cholecystectomy: training, economic, and patient benefits. Surg Endosc 19: 1082-1085.

28. Belena JM, Gracia JL, Ayala JL, Núñez M, Lorenzo JA, et al. (2011) The Laryngeal Mask Airway Supreme for positive pressure ventilation during laparoscopic cholecystectomy. J Clin Anesth 23: 456-460.

29. Maltby JR, Beriault MT, Watson NC (2001) Use of the laryngeal mask is not contraindicated for laparoscopic cholecystectomy. Anaesthesia 56: 800-802.

30. Kahla AH, Abdulhafez, Alhusainy M (2009) Comparison of Laryngeal mask airway-Supreme and Endotracheal tube in adult patients undergoing laparoscopic surgery. Ain Shams Journal of Anesthesiology 2: 73-85

31. Maltby JR, Beriault MT, Watson NC, Liepert D, Fick GH (2002) The LMA-ProSeal is an effective alternative to tracheal intubation for laparoscopic cholecystectomy. Can J Anaesth 49: 857-862.

32. Natalini G, Lanza G, Rosano A, Dell'Agnolo P, Bernardini A (2003) Standard Laryngeal Mask Airway and LMA-ProSeal during laparoscopic surgery. J Clin Anesth 15: 428-432.

33. Güleç H, Cakan T, Yaman H, Kilinç AS, Basar H (2012) Comparison of hemodynamic and metabolic stress responses caused by endotracheal tube and Proseal laryngeal mask airway in laparoscopic cholecystectomy. J Res Med Sci 17: 148-153

34. Belena JM, Núñez M, Anta D, Carnero M, Gracia JL, et al. (2013) Comparison of Laryngeal Mask Airway Supreme and Laryngeal Mask Airway Proseal with respect to oropharyngeal leak pressure during laparoscopic cholecystectomy: a randomised controlled trial. Eur J Anaesthesiol 30: 119-123.

35. Sharma B, Sehgal R, Sahai C, Sood J (2010) PLMA vs i-gel: A Comparative Evaluation of Respiratory Mechanics in Laparoscopic Cholecystectomy. J Anaesthesiol Clin Pharmacol 26: 451-457.

36. Cha SM, Park S, Kang H, Baek CW, Jung YH, et al. (2014) Gastric distension with SLIPA versus LMA ProSeal during laparoscopic cholecystectomy: a randomized trial. Surg Laparosc Endosc Percutan Tech 24: 216-220.
37. Chung CJ, Jang MK, Choi SR, Lee SC, Lee JH (2009) A comparative study of the Cobra perilaryngeal airway and Proseal laryngeal mask airway during laparoscopic cholecystectomy. Korean J Anesthesiol 56: 151-155.

38. Sharma B, Sahai C, Bhattacharya A, Kumra VP, Sood J (2003) Proseal laryngeal mask airway: a study of 100 consecutive cases of laparoscopic surgery. Indian J Anaesth 47: 467-472.

39. Maharjan SK (2013) I-gel for positive pressure ventilation. JNMA J Nepal Med Assoc 52: 255-259.

40. Saraswat N, Kumar A, Mishra A, Gupta A, Saurabh G, et al. (2011) The comparison of Proseal laryngeal mask airway and endotracheal tube in patients undergoing laparoscopic surgeries under general anaesthesia. Indian J Anaesth 55: 129-134.

41. Badheka JP, Jadliwala RM, Chhaya VA, Parmar VS, Vasani A, et al. (2015) I-gel as an alternative to endotracheal tube in adult laparoscopic surgeries: A comparative study. J Min Access Surg 11: 251-256.

42. Esa K, Azarinah I, Muhammad M, Helmi MA, Jaafar MZ (2011) A Comparison between Laryngeal Tube Suction II Airway ${ }^{\mathrm{TM}}$ and Proseal ${ }^{\mathrm{TM}}$ Laryngeal Mask Airway in Laparascopic Surgery. Med J Malaysia 66: 182-186.

43. Kang JE, Oh CS, Choi JW, Son IS, Kim SH (2014) Postoperative pharyngolaryngeal adverse events with Laryngeal Mask Airway (LMA Supreme) in laparoscopic surgical procedures with cuff pressure limiting 25 ? $\mathrm{cm} \mathrm{H}_{2} \mathrm{O}$ : prospective, blind, and randomised study. Scientific World Journal 1-7.

44. Jain MK, Venugopal M, Tripathi CB (2010) Use of Proseal LMA (PLMA) for Laparoscopic Cholecystectomies: An ABG Analysis. J Anaesth Clin Pharmacol 26: 87-90

45. Aydogmus MT, Turk HS, Oba S, Unsal O, Sinikoglu SN (2014) Can Supreme $^{\mathrm{TM}}$ laryngeal mask airway be an alternative to endotracheal intubation in laparoscopic surgery? Braz J Anesthesiol 64: 66-70.

46. Sharma B, Sood J, Sahai C, Kumra VP (2008) Efficacy and Safety Performance of Proseal ${ }^{\mathrm{TM}}$ Laryngeal Mask Airway in Laparoscopic Surgery: Experience of 1000 Cases. Indian Journal of Anaesthesia 52: 288-296.

47. Abdellatif AA, Ali MA (2011) Comparison of streamlined liner of the pharynx airway (SLIPA ${ }^{\mathrm{TM}}$ ) with the laryngeal mask airway Proseal ${ }^{\mathrm{TM}}$ for lower abdominal laparoscopic surgeries in paralyzed, anesthetized patients. Saudi J Anaesth 5: 270-276.

48. Maltby JR, Beriault MT, Watson NC, Liepert DJ, Fick GH (2003) LMA-Classic and LMA-ProSeal are effective alternatives to endotracheal intubation for gynecologic laparoscopy. Can J Anaesth 50: 71-77.

49. Lim Y, Goel S, Brimacombe JR (2007) The ProSeal laryngeal mask airway is an effective alternative to laryngoscope-guided tracheal intubation for gynaecological laparoscopy. Anaesth Intensive Care 35: 52-56.

50. Hohlrieder M, Brimacombe J, Eschertzhuber S, Ulmer H, Keller C (2007) A study of airway management using the ProSeal LMA laryngeal mask airway compared with the tracheal tube on postoperative analgesia requirements following gynaecological laparoscopic surgery. Anaesthesia 62: 913-918.

51. Griffiths JD, Nguyen M, Lau H, Grant S, Williams DI (2013) A prospective randomized comparison of the LMA ProSeal ${ }^{\mathrm{TM}}$ versus endotracheal tube on the severity of postoperative pain following gynaecological laparoscopy. Anaesth Intensive Care 41: 46-50.

52. Lee AK, Tey JB, Lim Y, Sia AT (2009) Comparison of the single-use LMA supreme with the reusable ProSeal LMA for anaesthesia in gynaecological laparoscopic surgery. Anaesth Intensive Care 37: 815-819.

53. Jeon WJ, Cho SY, Baek SJ, Kim KH (2012) Comparison of the Proseal LMA and intersurgical i-gel during gynecological laparoscopy. Korean J Anesthesiol 63: 510-514.

54. Roth H, Genzwuerker HV, Rothhaas A, Finteis T, Schmeck J (2005) The ProSeal laryngeal mask airway and the laryngeal tube Suction for ventilation in gynaecological patients undergoing laparoscopic surgery. Eur J Anaesthesiol 22: $117-122$. 
55. Miller DM, Camporota L (2006) Advantages of ProSeal and SLIPA airways over tracheal tubes for gynecological laparoscopies. Can J Anaesth 53: 188193.

56. Abdi W, Amathieu R, Adhoum A, Poncelet C, Slavov V, et al. (2010) Sparing the larynx during gynecological laparoscopy: a randomized trial comparing the LMA Supreme and the ETT. Acta Anaesthesiol Scand 54: 141-146.

57. Teoh WHL, Lee KM, Suhitharan T, Yahaya Z, Teo MM, et al. (2010) Comparison of the LMA Supreme vs the i-gel in paralysed patients undergoing gynaecological laparoscopic surgery with controlled ventilation. Anaesthesia 65: 1173-1179

58. Suhitharan T, Teoh WH (2013) Use of extraglottic airways in patients undergoing ambulatory laparoscopic surgery without the need for tracheal intubation. Saudi J Anaesth 7: 436-441.

59. Chattopadhyay S, Goswami S (2013) A comparative study of two disposable supraglottic devices in diagnostic laparoscopy in gynaecology. J South Asian Feder Obst Gynae 5: 124-128.

60. Chen BZ, Tan L, Zhang L, Shang YC (2013) Is muscle relaxant necessary in patients undergoing laparoscopic gynecological surgery with a ProSeal LMA $^{\mathrm{TM}}$ ? J Clin Anesth 25: 32-35.

61. Belena J, Núñez M, Gracia JL, Pérez JL, Yuste J (2012) The Laryngeal Mask Airway Supreme ${ }^{\mathrm{TM}}$ : safety and efficacy during gynaecological laparoscopic surgery. South Afr J Anaesth Analg 18: 143-147.
62. Mukadder S, Zekine B, Erdogan KG, Ulku O, Muharrem U, et al. (2015) Comparison of the proseal, supreme, and i-gel SAD in gynecological laparoscopic surgeries. ScientificWorldJournal 2015: 634320.

63. Sakka SG, Huettemann E, Petrat G, Meier-Hellmann A, Schier F, et al. (2000) Transoesophageal echocardiographic assessment of haemodynamic changes during laparoscopic herniorrhaphy in small children. $\mathrm{Br} \mathrm{J}$ Anaesth 84: 330 334.

64. Sinha A, Sharma B, Sood J (2007) ProSeal as an alternative to endotracheal intubation in pediatric laparoscopy. Paediatr Anaesth 17: 327-332.

65. Dave NM, lyer HR, Dudhedia U, Makwana J (2009) An evaluation of the proseal laryngeal mask airway in paediatric laparoscopy. J Anaesth Clin Pharmacol 25: 71-73.

66. Nicholson A, Cook TM, Smith AF, Lewis SR, Reed SS (2013) Supraglottic airway devices versus tracheal intubation for airway management during general anaesthesia in obese patients. Cochrane Database of Syst Rev 9: CD010105

67. Carron M, Veronese S, Gomiero W, Foletto M, Nitti D, et al. (2012) Hemodynamic and hormonal stress responses to endotracheal tube and ProSeal Laryngeal Mask Airway ${ }^{\mathrm{TM}}$ for laparoscopic gastric banding. Anesthesiology 117: 309-320. 